\title{
ANALISIS PEMBELAJARAN DARING BERDASARKAN TECHNOLOGY READINESS INDEX 2.0 MAHASISWA PENDIDIKAN MATEMATIKA UNIVERSITAS IVET
}

\author{
Lenny Kurniati ${ }^{1 *}$, Ratih Kusumawati ${ }^{2}$ \\ Universitas Ivet, Universitas Ivet \\ *Lennykurniati@gmail.com
}

Diterima: 02 Juli 2021. Disetujui: 15 Juli 2021. Dipublikasikan: 31 Juli 2021

\begin{abstract}
ABSTRAK
Kesiapan teknologi menjadi penting dalam pelaksanaan pembelajaran daring. Penelitian ini berfokus khususnya pada bagaimana kesiapan teknologi berperan dalam hasil pembelajaran daring selama masa pandemi covid-19. Tujuan utama dari penelitian ini adalah untuk melihat ada adanya pengaruh dari kesiapan teknologi yang terdiri atas empat aspek yaitu optimisme, inovatif, insecurity dan discomfort terhadap indeks prestasi mahasiswa. Penelitian ini dilakukan pada 34 mahasiswa Program Studi Pendidikan Matematika Universitas Ivet dengan menggunakan instrumen skala Technology Readiness Index 2.0. untuk data TRI, dan menggunakan data sekunder berupa dokumen untuk data IPK. Hasilnya menunjukkan bahwa Indeks Kesiapan Teknologi (TRI) berpengaruh secara signifikan terhadap Indeks Prestasi Kumulatif (IPK) mahasiswa Universitas Ivet dengan skor Pearson Correlation sebesar 0,517. TRI mempengaruhi IPK mahasiswa Universitas Ivet sebesar 26,8\%, sedangkan sisanya dipengaruhi oleh faktor lain yang tidak terukur dalam penelitian ini. Hasil data yang dianalisis diperoleh persamaan regresi $\hat{y}=2.666+0.03 x$ artinya setiap penambahan variabel TRI sebesar satu satuan, maka variabel IPK bertambah sebesar 0.03 satuan. Kesiapan teknologi dalam pembelajaran online membuat proses pembelajaran menjadi tidak terikat, terkesan lebih santai dan fleksibel. Penelitian lebih lanjut diperlukan untuk meningkatkan kesiapan teknologi mahasiswa menuju era pembelajaran online.
\end{abstract}

Kata kunci: Technology Readiness Index 2.0, pembelajaran daring, covid-19

\begin{abstract}
Technology readiness is important in the implementation of Online learning. This research focuses in particular on how technology readiness plays a role in Online learning outcomes during the COVID-19 pandemic. The main purpose of this study is to describe technology readiness from four aspects: optimism, innovation, insecurity and discomfort, and their effect on student achievement index. This research was conducted on 257 Ivet University students using the Technology readiness index 2.0 questionnaire instrument. The results show that Technology Readiness Index has a positive and significant effect on the Cumulative Achievement Index (GPA) of Ivet University students with a Pearson Correlation score of 0.517 . TRI affects the GPA of Ivet University students by $26,8 \%$, while the remaining is influenced by other factors that are not measured in this study. Regression equation is obtained $\hat{y}=2.666+0.03 x$, meaning that for each addition of the TRI variable by one unit, the GPA variable increases by 0.03 units. Technological readiness in Online learning makes the learning process more relaxed and flexible. Further research is recomended to improve students' technology readiness towards the era of Online learning.
\end{abstract}

Keywords: Technology Readiness Index 2.0, Online learning, covid-19

\section{Pendahuluan}

Pada Bulan Maret 2020, WHO menyatakan bahwa covid-19 menjadi pandemi. Seluruh negara di dunia beradaptasi agar kehidupan tetap berlangsung. Berbagai sektor penting seperti ekonomi, sosial, dan pendidikan harus berubah. Dalam hal pendidikan, perubahan besar-besaran terjadi. Perubahan yang sangat mendasar dalam pelaksanaan pendidikan. Covid-19 "memaksa" pendidik di seluruh dunia untuk 


\section{Range: Jurnal Pendidikan Matematika Vol. 3 No. 1 Tahun 2021 Lenny Kurniati, dkk}

mengubah pembelajaran di kelas menjadi pembelajaran online (Attard \& Holmes, 2020). Siswa dan guru dilarang bertemu di sekolah untuk melakukan kegiatan pembelajaran (Engelbrecht et al., 2020). Hal ini menciptakan kecemasan bagi tenaga kependidikan, siswa, dan orang tua (Green et al., 2020). Hingga muncul istilah panicgogy (panic+paedagogy) atas gentingnya permasalahan pendidikan dan upaya solusinya (Kamanetz, 2020).

Salah satu penyebab panicgogy adalah peralihan secara ekstrim dari pembelajaran di kelas menjadi pembelajaran daring. Tidak ada masa transisi dalam peralihan tersebut. Pembelajaran sepenuhnya bertumpu pada teknologi. "Melek" teknologi bagi mahasiswa maupun dosen menjadi salah satu kunci pelaksanaan pembelajaran daring. Sampai saat ini, sudah satu tahun penuh mahasiswa (termasuk mahasiswa Universitas Ivet) menjalani pembelajaran daring. Bukti keberhasilan pembelajaran tersebut salah satunya dapat dilihat melalui indeks prestasi mahasiswa.

Dengan kemajuan teknologi, peluang pelaksanaan e-learning di ruang kelas tradisional telah meningkat. Namun, untuk mendorong keterlibatan siswa terhadap e-learning, platform tersebut harus ramah siswa dan guru. Oleh karena itu, perlu eksplorasi determinan untuk memandu lembaga pendidikan dan pengembang platform online dalam mencapai keunggulan dalam peningkatan dan keterlibatan di antara siswa (Kaushik \& Agrawal, 2021).

Terdapat dua jenis pembelajaran online, yaitu pembelajaran sinkronus dan asinkronus. Tabel 1. berikut menyajikan perbedaan keduanya.

Tabel 1. Jenis pembelajaran Online

\begin{tabular}{|c|c|c|}
\hline & Sinkronus & Asinkronus \\
\hline Kapan? & $\begin{array}{l}\text { Diskusi tentang topik yang tidak terlalu kompleks } \\
-\quad \text { Pengenalan } \\
\text { - } \quad \text { Perencanaan } \\
-\quad \text { Pembelajaran }\end{array}$ & $\begin{array}{l}\text { Refleksi dan diskusi tentang topik } \\
\text { yang bersifat kompleks, } \\
\text { Mengatasi masalah keterbatasan } \\
\text { waktu yang menyebabkan tidak } \\
\text { dapat/sulit dilakukan komunikasi } \\
\text { sinkronus }\end{array}$ \\
\hline Mengapa? & $\begin{array}{l}\text { Siswa dapat lebih berkomitmen dan termotivasi } \\
\text { karena mendapat respon langsung }\end{array}$ & $\begin{array}{l}\text { Peserta didik memiliki waktu } \\
\text { lebih banyak untuk melakukan } \\
\text { refleksi karena respon atau } \\
\text { jawaban akan pertanyaan pengajar } \\
\text { tidak harus dijawab Langsung }\end{array}$ \\
\hline Bagaimana? & $\begin{array}{l}\text { Menggunakan media komunikasi seperti video } \\
\text { conferencing, instan } \\
\text { messaging, chat, dan dapat disertai pertemuan tatap } \\
\text { muka }\end{array}$ & $\begin{array}{l}\text { Menggunakan media komunikasi } \\
\text { tidak langsung seperti e-mail, } \\
\text { discussion board, ataupun blog }\end{array}$ \\
\hline Contoh & $\begin{array}{l}\text { Siswa bekerja sama secara berkelompok dan } \\
\text { berdiskusi melalui instan messaging atau chat untuk } \\
\text { saling berkenalan, membuat perencanaan belajar, dan } \\
\text { membagi tugas. Pengajar yang ingin menyampaikan } \\
\text { suatu konsep secara simple dapat menyampaikan } \\
\text { 'kuliah' secara live melalui video-conference }\end{array}$ & $\begin{array}{l}\text { Siswa diminta untuk melakukan } \\
\text { refleksi secara individual atas } \\
\text { materi yang sedang didiskusikan } \\
\text { dan meminta mereka menuliskan } \\
\text { hasil refleksinya secara esai (atau } \\
\text { dalam blog). } \\
\text { Siswa diminta menyampaikan } \\
\text { hasil refleksinya kepada peserta } \\
\text { lainnya dan kemudian mereka } \\
\text { diminta untuk saling } \\
\text { mengomentari. }\end{array}$ \\
\hline
\end{tabular}

Sumber: Hrastinski, 2008 


\section{Range: Jurnal Pendidikan Matematika Vol. 3 No. 1 Tahun 2021 Lenny Kurniati, dkk}

Pengetahuan dan keterampilan awal teknologi setiap mahasiswa berada pada tingkatan yang berbeda-beda. Sayangnya, peralihan yang berlangsung secara tiba-tiba ini belum memfasilitasi mahasiswa untuk mendapat pelatihan tentang pengetahuan dan keterampilan teknologi secara khusus. Saat ini, sebagian besar mahasiswa adalah digital native dan menggunakan teknologi dengan baik (Prensky, 2001). Namun, pemanfaatan teknologi pembelajaran yang dikombinasikan dengan pengajaran tradisional di dalam kelas masih menjadi pendekatan pengajaran yang sedang berkembang dan prediktor efektivitas pembelajaran masih belum jelas (Hao, et al, 2016).

Kesiapan teknologi siswa mengacu pada kecenderungan mereka untuk merangkul teknologi baru untuk mencapai tujuan dalam pembelajaran (Parasuraman, 2000). Penelitian tentang kesiapan pembelajaran daring menemukan bahwa tingkat kesiapan e-learning siswa dapat mempengaruhi tingkat keberhasilan dalam e-learning (Moftakhari, 2013; Piskurich \& Piskurich, 2003). Untuk memperoleh deskripsi yang baik tentang kesiapan teknologi mahasiswa, digunakan Technology Readiness Index. Technology Readiness Index merupakan angket khusus tentang kesiapan teknologi yang dikembangkan pertama kali oleh Parasuraman (2001) yang terdiri atas 4 aspek yaitu optimism, innovative, insecurity dan discomfort. Seiring berkembangnya teknologi, Parasuraman memperbaharui angket tersebut menjadi Technology Readiness Index 2.0 (TRI 2.0). Angket ini telah digunakan banyak peneliti dari berbagai belahan dunia seperti Badri, et al (2013) yang mengukur kesiapan teknologi guru di Dubai, Ariani (2018) menggunakan TRI pada pelaku UMKM di Indonesia, Penz (2017) pada pengusaha di USA, dan masih banyak lagi. Penelitian-penelitian tersebut menunjukkan hasil yang berbeda; ada yang mengandung hubungan positif, hubungan negatif, dan tidak ada hubungan yang signifikan antara penggunaan internet untuk materi kursus dan hasil belajar siswa (Gulek \& Demirtas, 2005; Shouping \& Kuh, 2001; Sana, Weston, \& Cepeda, 2013).

Untuk mengisi kesenjangan tersebut, perlu dilakukan eksplorasi dampak kesiapan teknologi mahasiswa Universitas Ivet dan pengaruhnya terhadap prestasi mahasiswa. Data tersebut dapat dijadikan bahan refleksi untuk perbaikan pelaksanaan pembelajaran daring berikutnya.

\section{Metode Penelitian}

Pengambilan data penelitian dilakukan di Universitas Ivet. Kurun waktu pengambilan data adalah pada bulan Desember 2020 sampai dengan Januari 2021. Hal ini dilakukan untuk merefleksi kesiapan teknologi mahasiswa setelah 1 tahun penuh mengikuti pembelajaran daring.

Penelitian ini merupakan penelitian kuantitatif dengan desain korelasional. Variabel yang diukur antara lain kesiapan teknologi mahasiswa sebagai variabel bebas dan Indeks prestasi mahasiswa sebagai variabel terikat. Kesiapan teknologi yang merupakan survei dengan skala diperoleh dalam bentuk data ordinal, yang selanjutnya dikonversi menjadi data interval dengan menggunakan Metode Suksesiv Interval (MSI) supaya dapat dianalisis secara parametris bersama data IPK mahasiswa yang juga termasuk jenis data interval.

Sebelum dilakukan pengujian korelasi terlebih dahulu dilakukan uji normalitas untuk mengetahui bahwa data dalam kondisi normal dan siap diuji lebih lanjut. Data dari masing-masing variabel kemudian dianalisis menggunakan uji korelasi product moment untuk mengetahui ada tidaknya hubungan antara kedua variabel. Selanjutnya apabila ditemukan adanya hubungan antara kedua variabel dilakukan pengujian lanjut berupa uji regresi untuk mengetahui seberapa besar pengaruh variabel bebas terhadap variabel terikatnya.

Metode pengumpulan data dalam penelitian ini adalah pengisian angket. Angket kesiapan teknologi menggunakan Technology Readiness Index 2.0 (Parasuraman, 2014) yang terdiri atas 16 butir pernyataan dari 4 aspek yaitu aspek optimisme, innovative, discomfort, dan insecurity. 


\section{Range: Jurnal Pendidikan Matematika Vol. 3 No. 1 Tahun 2021 Lenny Kurniati, dkk}

Technology Readiness adalah kombinasi dari keyakinan terkait teknologi yang positif dan negatif. Keyakinan ini diasumsikan bervariasi di antara individu. Secara kolektif, keyakinan yang ada bersama ini menentukan kecenderungan seseorang untuk berinteraksi dengan teknologi baru (Parasuraman dkk, 2001). Empat dimensi Technology Readiness adalah (Parasuraman, 2000): (1) Optimism didefinisikan sebagai pandangan positif tentang teknologi dan keyakinan yang menawarkan peningkatan kontrol, fleksibilitas, dan efisiensi kepada orang-orang dalam kehidupan mereka (Parasuraman dkk, 2001). Secara umum menangkap perasaan positif tentang teknologi; (2) Innovativeness didefinisikan sebagai "kecenderungan untuk menjadi pelopor teknologi dan pemimpin pemikiran". Dimensi ini umumnya mengukur sejauh mana individu memandang diri mereka sebagai yang terdepan; (3) Discomfort didefinisikan sebagai "kurangnya kontrol atas teknologi dan perasaan kewalahan olehnya" (Parasuraman dkk, 2001). Dimensi ini umumnya mengukur ketakutan dan kekhawatiran yang dialami orang ketika dihadapkan dengan teknologi; dan (4) Insecurity didefinisikan sebagai "ketidakpercayaan terhadap teknologi dan skeptisisme tentang kemampuannya untuk bekerja dengan baik" (Parasuraman dkk, 2001).

Alat ukur yang digunakan untuk mengukur kesiapan teknologi dalam penelitian ini adalah skala. Skala merupakan salah satu metode pengumpulan data yang baik, karena seperangkat pertanyaan yang ada dalam skala merupakan pernyataan yang secara logis ada kaitannya dengan masalah yang diteliti (Azwar, 1999). Metode skala ini digunakan untuk mengungkap respon pribadi subjek. Penelitian ini menggunakan model skala Likert dengan empat alternatif jawaban, antara lain (SS) sangat sesuai, (S) sesuai, (TS) tidak sesuai, (STS) sangat tidak sesuai. Skala Likert digunakan untuk mengukur sikap, pendapat, dan persepsi seseorang atau sekelompok orang tentang fenomena sosial. Masing-masing skala diharapkan mampu mengungkapkan berbagai aspek yang hendak diukur. Penggunaan skala dalam penelitian ini didasari pada asumsi bahwa yang paling memahami seorang individu adalah dirinya sendiri. Skala Likert ini meniadakan kategori jawaban di tengah berdasarkan beberapa alasan yaitu: kategori undecided tersebut memiliki arti ganda, belum dapat memutuskan, dan belum dapat memberi jawaban.

Sedangkan indeks prestasi mahasiswa yang dimaksud dalam penelitian ini adalah indeks prestasi mahasiswa pendidikan matematika Universitas Ivet semester gasal 2020/2021, karena pada semester ini mahasiswa melakukan pembelajaran daring secara penuh.

Data yang diperoleh dalam penelitian ini kemudian dianalisis secara statistik parametris berupa uji regresi untuk menguji ada atau tidak dan besarnya pengaruh kesiapan teknologi terhadap indeks prestasi mahasiswa. Sebelum dilakukan pengujian regresi ini terlebih dahulu dilakukan uji prasyarat untuk melihat kelayakan model regresi linier sederhana berupa uji normalitas dan uji liniearitas.

\section{Hasil Penelitian dan Pembahasan}

Responden pada penelitian ini adalah mahasiswa Pendidikan Matematika Universitas Ivet yang telah melaksanakan proses pembelajaran daring selama minimal 2 semester penuh. Terdiri dari mahasiswa program studi pendidikan matematika dari berbagai angkatan sejumlah 34 mahasiswa.

Sebelum melaksanakan pengujian hipotesis terlebih dahulu dilakukan uji prasyarat yakni uji normalitas, uji linearitas, dan uji heterokedastisitas. Uji normalitas data bertujuan untuk mengetahui apakah data berdistribusi normal atau tidak. Pengujian normalitas dapat dilakukan dengan beberapa metode, diantaranya adalah analisis visual dengan menampilkan histogram, boxplot, dan Q-Q plot atau dengan analisis statistik yang dapat dilakukan dengan uji Kolmogorov-Smirnov dan Shapiro-Wilk. Pengujian normalitas pada data penelitian ini ditunjukkan oleh Tabel 2. berikut:

Tabel 2. Uji Normalitas Data

One-Sample Kolmogorov-Smirnov Test

\begin{tabular}{rr}
\hline $\mathrm{N}$ & Unstandardized Residual \\
\hline $\mathrm{N}$
\end{tabular}




\begin{tabular}{llr} 
Normal Parameters & Mean & .0000000 \\
& Std. Deviation & .18548505 \\
Most Extreme Differences & Absolute & .138 \\
& Positive & .080 \\
& Negative & -.138 \\
Test Statistic & & .138 \\
Asymp. Sig. (2-tailed) & & $\mathbf{. 1 0 2}$ \\
\hline
\end{tabular}

Berdasarkan tabel output SPSS tersebut, diperoleh nilai signifikansi asymp.Sig (2-tailed) sebesar 0,102 lebih dari 0,05. Dengan demikian dapat disimpulkan data berdistribusi normal sehingga asumsi normalitas dalam model regresi sudah terpenuhi.

Uji prasyarat lain yang diperlukan sebelum pengujian hipotesis regresi adalah uji linieritas yang bertujuan untuk mengetahui apakah dua variabel mempunyai hubungan yang linear secara signifikan atau tidak. Korelasi yang baik seharusnya terdapat hubungan yang linear antara variabel prediktor dan variabel kriteria. Hasil pengujian linieritas pada penelitian ini ditunjukkan pada Tabel 3. berikut:

Tabel 3. Uji linieritas

ANOVA Table

\begin{tabular}{|c|c|c|c|c|c|c|c|}
\hline \multirow{4}{*}{\multicolumn{2}{|c|}{ IPK * TRI Between Groups }} & & Sum of Squares & $\mathrm{df}$ & Mean Square & $\mathrm{F}$ & Sig. \\
\hline & & (Combined) & .982 & 12 & .082 & 3.022 & .013 \\
\hline & & Linearity & .415 & 1 & .415 & 15.330 & .001 \\
\hline & & Deviation from Linearity & .567 & 11 & .052 & 1.903 & .099 \\
\hline & Within Groups & & .569 & 21 & .027 & & \\
\hline & Total & & 1.550 & 33 & & & \\
\hline
\end{tabular}

Berdasarkan tabel 3 di atas diperoleh bahwa nilai deviation from linearity sig. Adalah sebesar 0,099 lebih besar dari 0,05. Maka dapat disimpulkan bahwa ada hubungan linear secara signifikan antara kedua variabel.

Setelah asumsi terpenuhi selanjutnya dilaksanakan Uji korelasional yang bertujuan untuk mengetahui ada tidaknya hubungan antara variabel bebas dan variabel terikat. Uji korelasi dalam penelitian ini menggunakan bantuan program SPSS dan diperoleh hasil seperti tampak pada Tabel 3. Hasil pengujian menunjukkan skor Pearson Correlation antara variabel TRI dan IPK adalah sebesar 0,517. Skor $r$ tersebut terletak dalam interval $0,4<r<0,6$ sehingga korelasi termasuk dalam kriteria sedang. Oleh karena itu dapat disimpulkan bahwa terdapat hubungan yang positif dan berkorelasi sedang. Sedangkan nilai signifikansi menunjukkan $0.00<0.01$ menunjukkan bahwa kedua variabel memiliki korelasi/hubungan. Sehingga dapat disimpulkan bahwa terdapat hubungan positif antara Indeks Kesiapan Teknologi (TRI) dan Indeks Prestasi Kumulatif (IPK) pada mahasiswa Universitas Ivet.

Tabel 4. Uji Korelasi

Correlations

\begin{tabular}{llrr}
\hline & & \multicolumn{1}{c}{ IPK } & \multicolumn{1}{c}{ TRI } \\
\hline IPK & Pearson Correlation & 1 & $.517^{* *}$ \\
& Sig. (2-tailed) & & .002 \\
& N & 34 & 34 \\
TRI & Pearson Correlation & $.517^{* *}$ & 1 \\
& Sig. (2-tailed) & .002 & \\
& N & 34 & 34 \\
\hline
\end{tabular}

**. Correlation is significant at the 0.01 level (2-

tailed). 


\section{Range: Jurnal Pendidikan Matematika Vol. 3 No. 1 Tahun 2021 \\ Lenny Kurniati, dkk}

Selanjutnya dilakukan pengujian untuk mengetahui seberapa besar pengaruh indeks kesiapan teknologi (TRI) terhadap IPK mahasiswa universitas Ivet. Pengujian dengan uji regresi dilakukan menggunakan SPSS dan menunjukkan hasil seperti pada Tabel 5. Hasil pengujian menunjukkan skor $R$ square atau koefisien determinasi sebesar 0,268 yang artinya TRI mempengaruhi IPK sebesar 26,8\%, sedangkan sisanya dipengaruhi oleh faktor lain yang tidak terukur dalam penelitian ini.

Tabel 5. Uji koefisien determinasi Model Summary ${ }^{\mathrm{b}}$

\begin{tabular}{lrrrr}
\hline Model & $\mathrm{R}$ & R Square & $\begin{array}{c}\text { Adjusted R } \\
\text { Square }\end{array}$ & $\begin{array}{l}\text { Std. Error of } \\
\text { the Estimate }\end{array}$ \\
\hline 1 & $.517^{\mathrm{a}}$ & .268 & .245 & .18836 \\
\hline
\end{tabular}

a. Predictors: (Constant), TRI

b. Dependent Variable: IPK

Selanjutnya dilakukan Uji signifikansi yang bertujuan untuk mengetahui apakah pengaruh variabel bebas terhadap variabel terikat signifikan atau tidak. Pengujian signifikansi ini dilakukan dengan menggunakan uji Anova pada SPSS. Dasar pengambilan keputusan adalah apabila signifikansi kurang dari 0,05 maka pengaruh signifikan dan berlaku sebaliknya.

Tabel 6. Uji signifikansi

ANOVA $^{\mathrm{a}}$

\begin{tabular}{|c|c|c|c|c|c|c|}
\hline Model & & $\begin{array}{l}\text { Sum of } \\
\text { Squares }\end{array}$ & $\mathrm{df}$ & Mean Square & $\mathrm{F}$ & Sig. \\
\hline \multirow[t]{3}{*}{1} & Regression & .415 & 1 & .415 & 11.699 & $.002^{\mathrm{b}}$ \\
\hline & Residual & 1.135 & 32 & .035 & & \\
\hline & Total & 1.550 & 33 & & & \\
\hline
\end{tabular}

a. Dependent Variable: IPK

b. Predictors: (Constant), TRI

Berdasarkan hasil uji signifikansi sesuai dengan yang tampak pada Tabel 6 diperoleh bahwa nilai signifikansi $0,002<0,05$ sehingga dapat ditarik kesimpulan bahwa variabel TRI berpengaruh secara signifikan terhadap variabel IPK mahasiswa.

Uji hipotesis Analisis regresi mempelajari hubungan yang diperoleh dinyatakan dalam persamaan matematika yang menyatakan hubungan fungsional antara variabel-variabel. Hubungan fungsional antara satu variabel prediktor dengan satu variabel kriterium disebut analisis regresi sederhana (tunggal), sedangkan hubungan fungsional yang lebih dari satu variabel disebut analisis regresi ganda.

Tabel 7. Pengujian persamaan regresi

Coefficients $^{\mathrm{a}}$

\begin{tabular}{|c|c|c|c|c|c|c|}
\hline \multirow[b]{2}{*}{ Model } & & \multicolumn{5}{|c|}{ Standardized } \\
\hline & & $\mathrm{B}$ & Std. Error & Beta & $\mathrm{t}$ & Sig. \\
\hline 1 & (Constant) & 2.666 & .275 & & 9.695 & .000 \\
\hline & TRI & .030 & .009 & .517 & 3.420 & .002 \\
\hline
\end{tabular}

a. Dependent Variable: IPK 


\section{Range: Jurnal Pendidikan Matematika Vol. 3 No. 1 Tahun 2021 Lenny Kurniati, dkk}

Tabel 7 menunjukkan persamaan regresi dari variabel TRI dan IPK. Diperoleh persamaan regresi $\hat{y}=2.666+0.03 x$, artinya setiap penambahan variabel TRI sebesar satu satuan, maka variabel IPK bertambah sebesar 0.03 satuan.

Hubungan positif yang cukup besar dari hasil analisis data yang diperoleh, memiliki arti kesiapan teknologi berperan dalam pencapaian prestasi siswa. Siap teknologi akan membantu siswa terbiasa dengan pembelajaran Online. Hal ini juga sejalan dengan penelitian Dunwill (2016) dalam beberapa praktik baik pembelajaran Online yang ditelitinya. Pada dasarnya prinsip mengajar pada pembelajaran Online sama dengan pada pembelajaran tatap muka, yaitu memperkenalkan konsep dan keterampilan yang harus dipelajari, menuntun siswa untuk melakukan proses belajar, dan memberikan latihan-latihan mandiri yang harus dilakukan oleh siswa. Namun demikian, menurut Dunwill setidaknya ada enam (6) prinsip dasar mengajar Online yang harus diperhatikan di atas aspek-aspek tersebut.

1. Kontak siswa - pengajar

2. Kolaborasi antar siswa

3. Suasana belajar aktif

4. Umpan balik yang cepat

5. Tujuan pembelajaran yang dapat dicapai

6. Penghargaan atas perbedaan.

Dari 16 item TRI 2.0 yang diisi oleh responden, pernyataan "Saya berpikir bahwa sistem teknologi tidak dibuat untuk digunakan oleh masyarakat yang awam" memiliki skor terendah yaitu 2,38. Hal ini berarti bahwa responden kurang setuju dengan pernyataan tersebut. Penelitian ini menunjukkan temuan penting bahwa responden menganggap teknologi untuk semua golongan masyarakat, termasuk masyarakat awam.

Sebaliknya, pernyataan "Teknologi membuat saya menjadi lebih bebas dalam melakukan pembelajaran dimana saja" menempati skor tertinggi 4,38. Proses pembelajaran menjadi tidak terikat, terkesan lebih santai dan fleksibel. Sejalan dengan pernyataan Gilbert (2015) bahwa pembelajaran Online bersifat fleksibel, pembelajaran Online memungkinkan siswa untuk bekerja pada waktu dan tempat yang sesuai dengan kebutuhan belajar mereka. Dukungan ini juga disampaikan oleh You \& Kang (2014) bahwa pembelajaran Online terbukti kondusif bagi siswa yang menyukai pembelajaran mandiri.

\section{Kesimpulan}

Simpulan

Berdasarkan hasil penelitian ini dapat disimpulkan bahwa Indeks Kesiapan Teknologi (TRI) berpengaruh secara positif dan signifikan terhadap Indeks Prestasi Kumulatif (IPK) mahasiswa Universitas Ivet dengan rincian sebagai berikut: (1) Terdapat hubungan yang erat dan positif antara TRI dan IPK mahasiswa Universitas Ivet yang ditunjukkan dengan skor Pearson Correlation sebesar 0,517, (2) Hasil pengujian menunjukkan skor $R$ square atau koefisien determinasi sebesar 0,268 yang artinya TRI mempengaruhi IPK mahasiswa Universitas Ivet sebesar 26,8\%, sedangkan sisanya dipengaruhi oleh faktor lain yang tidak terukur dalam penelitian ini, dan (3) Diperoleh persamaan regresi $\hat{y}=2.666+$ $0.03 x$, artinya setiap penambahan variabel TRI sebesar satu satuan, maka variabel IPK bertambah sebesar 0.03 satuan

Saran

Saran yang dapat dikembangkan berdasarkan hasil penelitian ini antara lain: (1) Perlu dilakukan penelitian lanjutan untuk meningkatkan indeks kesiapan teknologi pada mahasiswa Universitas Ivet sehingga dapat meningkatkan prestasi akademik mahasiswa; (2) Perlunya ketersediaan sarana teknologi dan pembiasaan pada mahasiswa universitas Ivet untuk meningkatkan indeks kesiapan teknologi secara cepat pada era sekarang dan selanjutnya; dan (3) Pembiasaan penggunaan teknologi secara optimal oleh 


\section{Range: Jurnal Pendidikan Matematika Vol. 3 No. 1 Tahun 2021 \\ Lenny Kurniati, dkk}

dosen Universitas Ivet yang terintegrasi dalam setiap mata kuliah dan proses pembelajaran sehingga dapat mempercepat peningkatan TRI mahasiswa.

\section{Daftar Pustaka}

Ariani, A. F., Napitupulu, D., Jati, R. K., Kadar, J. A., \& Syafrullah, M. (2018, April). Testing of Technology readiness index Model based on exploratory factor analysis approach. In Journal of Physics: Conference Series (Vol. 1007, No. 1, p. 012043). IOP Publishing.

Attard, C., \& Holmes, K. (2020). An exploration of teacher and student perceptions of blended learning in four secondary mathematics classrooms. Mathematics Education Research Journal 1-22

Azwar, S. (1999). Penyusunan skala psikologi. Yogyakarta: Pustaka pelajar.

Badri, M., Al Rashedi, A., \& Mohaidat, J. (2013, March). School teachers' technology readiness-An empirical study applying readiness factors and teacher type categorization. In Proceedings of the 2013 International Conference on Information, Business and Education Technology (ICIBET 2013). Atlantis Press.

Badri, M., Al Rashedi, A., Yang, G., Mohaidat, J., \& Al Hammadi, A. (2014). Technology Readiness of School Teachers: An Empirical Study of Measurement and Segmentation. Journal of Information Technology Education, 13.

Colby, C. L., \& Parasuraman, A. (2001). Techno-ready marketing: How and why customers adopt technology. Simon and Schuster.

Dunwill, E. (2016). Teaching principles transferred to Online courses: Strategies to use eLearning Best Practices.

Engelbrecht, J., Borba, M. C., Llinares, S., \& Kaiser, G. (2020). Will 2020 be remembered as the year in which education was changed? Springer.

Gilbert, B. (2015). Online learning revealing the benefits and challenges.

Green, J. K., Burrow, M. S., \& Carvalho, L. (2020). Designing for transition: Supporting teachers and students cope with emergency remote education. Postdigital Science and Education, 2(3), 906-922

Gulek, J. C., \& Demirtas, H. (2005). Learning with technology: The impact of laptop use on student achievement. Journal of Technology, Learning, and Assessment, 3(2)

Hao, Q., Wright, E., Barnes, B., \& Branch, R. M. (2016). What are the most important predictors of computer science students' Online help-seeking behaviors?. Computers in Human Behavior, 62, 467-474.

Hrastinski, S. (2008). Asynchronous and synchronous e-learning. Educause quarterly, 31(4), 51 55. 


\section{Range: Jurnal Pendidikan Matematika Vol. 3 No. 1 Tahun 2021 Lenny Kurniati, dkk}

Kamanetz, A. (2020). Panic-gogy': Teaching Online classes during the coronavirus pandemic. NPR (19 March).

Kaushik, M. K., \& Agrawal, D. (2021). Influence of technology readiness in adoption of elearning. International Journal of Educational Management.

Moftakhari, M. M. (2013). Evaluating e-learning readiness of faculty of letters of Hacettepe.

Parasuraman, A. (2000). Technology readiness index (TRI) a multiple-item scale to measure readiness to embrace new technologies. Journal of service research, 2(4), 307-320.

Parasuraman, A., \& Colby, C. L. (2015). An updated and streamlined technology readiness index: TRI 2.0. Journal of service research, 18(1), 59-74.

Penz, D., Amorim, B. C., do Nascimento, S., \& Rossetto, C. R. (2017). The influence of technology readiness index in entrepreneurial orientation: A study with Brazilian entrepreneurs in the United States of America. International Journal of Innovation: IJI Journal, 5(1), 66-76.

Piskurich, G. M., \& Piskurich, J. F. (2003). Utilizing a classroom approach to prepare learners for E-Learning. Preparing Learners for E-Learning, 45-72.

Prensky, M. (2001). Digital natives, digital immigrants part 2: Do they really think differently?. On the horizon.

Sana, F., Weston, T., \& Cepeda, N. J. (2013). Laptop multitasking hinders classroom learning for both users and nearby peers. Computers \& Education, 62, 24e31

Shouping, H., \& Kuh, G. D. (2001). Computing Experience and Good Practices in Undergraduate Education: Does the Degree.of Campus" Wiredness" Matter?. Education Policy Analysis Archives, 9(49).

You, J. W., \& Kang, M. (2014). The role of academic emotions in the relationship between perceived academic control and self-regulated learning in Online learning. Computers \& Education, 77, 125-133. 